\title{
The Initial Assessment of Nurse Knowledge to Response Time in Traffic Accident Case
}

\section{Nandang DD Khairari ${ }^{1}$}

1 Prodi Ilmu Keperawatan STIKes Hamzar Mamben Lombok Timur

\begin{tabular}{|c|c|}
\hline Article Info & Abstract \\
\hline $\begin{array}{l}\text { Article History: } \\
\text { Submitted: April } 7^{\text {th }}, 2021 \\
\text { Accepted: May } 30^{\text {th }}, 2021 \\
\text { Published: May } 31^{\text {st }}, 2021 \\
\text { Keywords: } \\
\text { Initial Assessment; } \\
\text { Response Time; } \\
\text { Traffic Accident Cases }\end{array}$ & $\begin{array}{l}\text { The occurrence of patients with traffic accidents is increased so much that } \\
\text { the nurses need to enhance the knowledge of the response time services in } \\
\text { the service of traffic accident cases. This research is to define the } \\
\text { relationship between the nurses' knowledge level to the initial assessment } \\
\text { of the nurses' response time in the service of traffic accident cases in the } \\
\text { emergency departments. The study was conducted in the emergency room } \\
\text { of Dr. R. Soedjono Selong Hospital. The study was quantitative with cross- } \\
\text { sectional planning. Total sampling was used and obtained } 25 \text { respondents. } \\
\text { The results showed that nurses' knowledge level is } 80 \% \text { categorized as well, } \\
16 \% \text { categorized as moderate and } 4 \% \text { categorized as low. For nurse } \\
\text { response time, } 96 \% \text { categorized as fast and } 4 \% \text { categorized as slow. The } \\
\text { statistical test was used the chi-square test with SPSS. The P-value is } 0,000 \text {, } \\
\text { which implies there is a relationship between nurse knowledge level to the } \\
\text { initial assessment of the nurses' response time in the service of traffic } \\
\text { accident cases. }\end{array}$ \\
\hline
\end{tabular}

\section{PENDAHULUAN}

Instalasi Gawat Darurat (IGD) adalah instalasi yang menangani pasien yang dalam kondisi kegawatdaruratan dengan dilengkapi oleh pemberi pelayanan yang sudah memiliki keterampilan dalam bidang gawat darurat. [1].

Pelayanaan pasien yang dalam kondisi gawat darurat merupakan sesuatu yang sangat penting mengingat IGD Sebagai pintu terdepan rumah sakit. IGD harus memberikan pertolongan yang cepat dan tepat untuk keselamatan pasien. Penelitian lain menunjukkan pentingnya waktu reaksi/waktu tanggap kecepatan pertolongan yang diberikan kepada pasien memiliki waktu yang terstandar untuk mendapatkan hasil penanganan yang tepat [2]. Ruang IGD merupakan ruangan dimana pasien mendapatkan perawatan pertama kalinya. Salah satu kasus yang banyak terjadi di IGD adalah kecelakaan lalu lintas [3].

Jumlah kecelakaan lalu lintas terus meningkat di seluruh dunia, pada tahun 2000, didapatkan data sebanyak 1,15 juta kasus kecelakaan lalu lintas dan pada tahun 2018 bertambah menjadi 1,35 juta kasus [4]. Diperkirakan kecelakaan lalu lintas akan menduduki peringkat ke-3 setelah penyakit jantung koroner dan depresi berat dalam

Corresponding author:

Nandang DD Khairari

dhe2304@gmail.com

Media Keperawatan Indonesia, Vol 4 No 2, May 2021

e-ISSN: 2615-1669

ISSN: 2722-2802

DOI: $10.26714 / \mathrm{mki} .4 .2 .2021 .127-132$ 
penyebab kematian di dunia pada tahun 2020 [5].

Jumlah korban kecelakan lalu lintas di Nusa Tenggara Barat (NTB) tercatat korban yang meninggal dunia pada tahun 2017 sebanyak 473 orang, tahun 2018 mencapai 562 orang dan tahun 2019 sebanyak 526 orang [6]. Angka kecelakaan lalu lintas di Lombok timur terbilang cukup cukup tinggi dengan capaian angka kecelakaan sebesar 384 pada tahun 2019 [7].

Data yang diperoleh dari rekam medis RSUD Selong menunjukkan bahwa jumlah kunjungan pasien ke IGD pada tahun 2017 sebanyak 23.527 pasien, dengan rata-rata kunjungan setiap bulan 1.353 pasien. Diagnosa medis kecelakaan lalu lintas menempati posisi tertinggi tahun 2017 bulan Juni sebanyak 165 pasien.

Perawat di IGD harus memiliki kemampuan untuk memberikan pelayanan asuhan keperawatan yang cepat dan tepat sehingga perawat di IGD akan dituntut untuk memiliki seritifikat kemampuan khusus yang berupa PPGD (Pertolongan Pertama Gawat Darurat).

Bersamaan dengan peningkatan pelayanan yang harus diberikan kepada pasien yang menghadapi keadaan krisis, petugas medis yang bekerja di UGD diperlukan untuk memiliki informasi, kemampuan dan kemampuan yang mahir dalam memberikan perawatan berkualitas kepada pasien di mana petugas harus tersedia 24 jam setiap harinya [8].

Initial assessment/penilaian awal adalah siklus penilaian cepat terhadap pasien gawat dan kritis yang diikuti oleh tindakan resusitasi [9]. Perawat harus menyelesaikan pengkajian fisik dan psikososial secara cepat dan berkelanjutan untuk melihat masalah keperawatan yang muncul dalam ruang lingkup kegawatdaruratan. Pengkajian adalah cara yang efektif untuk mengetahui masalah kegawatdaruratan. Terdapat dua pengkajian dalam keperawatan yaitu pengkajian primer (primary survey) dan pengkajian sekunder (secondary survey). Pengetahuan tentang initial assessment yang dimiliki perawat masih kurang dimana hal ini tentunya dapat mempengaruhi tindakan tepat yang harus didapatkan klien [10].

Apabila tidak dilakukan pertolongan dengan cepat dan tepat pada kasus kegawatdaruratan, hal yang akan terjadi adalah terancamnya jiwa ataupun kecacatan pada anggota tubuh pasien. Sehingga pelaksanaan initial assessment merupakan salah satu hal yang sangat penting sebagai indikator dalam mengukur keberhasilan penanganan pasien pada kasus-kasus gawat darurat.

Instalasi Gawat Darurat merupakan bagian utama dalam pelayanan rumah sakit. Jika pelayanan di IGD sudah baik, maka gambaran dari suatu rumah sakit tersebut dapat dikatakan baik. Keberhasilan suatu tindakan dalam pelayanan merupakan sebuah prestasi bagi layanan Rumah Sakit. Penelitian ini bertujuan untuk mengetahui hubungan tingkat pengetahuan dengan respon time perawat gawat darurat dalam mengelola pasien kecelakaan lalu lintas. Oleh karena itu, penelitian ini dilakukan dengan tujuan untuk mengetahui hubungan/keterkaitan antara pengetahuan perawat IGD tentang initial assessment dengan cekepatan response time perawat dalam menangani pasien kecelakaan.

\section{METODE}

Penelitian ini menggunakan desain penelitian kuantitatif deskriptif dengan pendekatan cross-sectional. Penelitian ini mengkaji tentang hubungan tingkat pengetahuan dan respon time perawat gawat darurat dalam mengelola pasien kecelakaan. Penelitian ini dilakukan di instalasi gawat darurat RSUD Dr. R Soedjono Selong selama periode waktu antara bulan September hingga Oktober 2019. 
Responden penelitian ini adalah perawat gawat darurat yang sedang bertugas di instalasi gawat darurat. Responden penelitian ini berjumlah 25 orang perawat, yang didapatkan melalui total sampling. Kriteria inklusi responden yang telah diaur peneliti, antara lain: memiliki sertifikat PPGD, dapat berkomunikasi dengan baik dan bersedia menjadi responden.

Responden yang memenuhi kriteria, kemudian diberikan penjelasan tentang penelitian dan konsekuensi yang harus dilakukan selama penelitian. Responden yang telah menyetujui untuk menjadi responden diminta menandatangani informed consent. Setelah menandatangani lembar informed consent, responden diberikan kesempatan untuk mengisi instrument penelitian pada proses pengambilan data.

Pengumpulan data dilakukan dengan menggunakan kuisioner dan lembar observasi. Kuisioner digunakan untuk mendapatkan data tentang pengetahuan perawat dan lembar observasi digunakan untuk mendapatkan data respon time perawat. Kuisioner diisi oleh perawat dan lembar observasi diisi oleh peneliti. Kuisionernya yaitu kuisioner pengetahuan tentang initial assessment yang berisi 20 item yang telah dilakukan uji validitas dan reabilitas kepada 20 orang dan telah dinyatakan valid dengan nilai chronbach's alpha 0,903 .

Data hasil penelitian yang telah didapatkan oleh peneliti kemudian dilakukan tahap editing dan tabulating. Peneliti tidak mencantumkan identitas responden dalam laporan penelitian untuk menjaga kerahasiaan responden. Setelah semua data didapatkan, peneliti melakukan analisa data. Analisis data yang digunakan adalah analisis univariate dan bivariate. Analisis univariate untuk menyajikan karakteristik data responden dan analisis bivariate untuk mengetahui hubungan dua variable. Uji bivariate yang digunakan adalah uji chi square dengan derajat kepercayaan 95\%.

\section{HASIL}

Berdasarkan hasil penelitian dari total 25 sampel, mayoritas responden dalam penelitian ini berjenis kelamin laki-laki (52\%) dengan rata-rata usia antara 25-30 tahun $(80 \%)$ dan memiliki latar belakang pendidikan profesi Ners (84\%).

Tabel 1

Karakteristik Perawat IGD RSUD Dr. R Soedjono Selong $(n=25)$

\begin{tabular}{lcc}
\hline \multicolumn{1}{c}{ Indikator } & $\mathrm{f}$ & $\%$ \\
\hline Jenis Kelamin & & \\
Laki-laki & 13 & 52 \\
Perempuan & 12 & 48 \\
\hline Usia & & \\
$25-30$ & 20 & 80 \\
$31-40$ & 4 & 16 \\
$>40$ & 1 & 4 \\
\hline Pendidikan & & \\
D3 & 4 & 16 \\
Ners & 21 & 84 \\
\hline Tingkat Pengetahuan & & \\
Baik & 20 & 80 \\
Cukup & 4 & 16 \\
Kurang & 1 & 4 \\
\hline Response time & & \\
Cepat & 24 & 96 \\
Lambat & 1 & 4 \\
\hline
\end{tabular}

Hasil penelitian ini juga mendeskripsikan bahwa mayoritas perawat IGD RSUD Dr. Soedjono memiliki tingkat pengetahuan tentang inniial assessment dalam kategori baik $(80 \%)$ dan termasuk dalam klasifikasi perawat dengan respon time pada pelayanan kasus KLL dengan kategori cepat (96\%). (Tabel 1)

Tabel 2

Hubungan tingkat pengetahuan perawat terhadap response time perawat

\begin{tabular}{|c|c|c|c|}
\hline \multirow{2}{*}{ Indikator } & \multicolumn{2}{|c|}{ Respon Time Perawat } & \multirow[b]{2}{*}{$p$} \\
\hline & Cepat & Lambat & \\
\hline \multicolumn{4}{|c|}{ Tingkat Pengetahuan } \\
\hline \multicolumn{4}{|c|}{ Perawat } \\
\hline Baik & $20(80 \%)$ & $0(\%)$ & $0,000^{*}$ \\
\hline Cukup & $4(16 \%)$ & $0(\%)$ & \\
\hline Kurang & $0(0 \%)$ & $1(4 \%)$ & \\
\hline
\end{tabular}

* Chi-Square test

Selain itu, hasil uji statisitik pada penelitian ini menunjukkan hubungan yang signifikan antara tingkat pengetahuan perawat tentang initial assessment dengan respon 
time perawat pada pelayanan kasus kecelakaan lalu lintas di IGD RSUD Dr. R. Soedjono Selong $(\mathrm{p}<0.05)$. (Tabel 2)

\section{PEMBAHASAN}

\section{Tingkat pengetahuan perawat tentang initial assessment}

Hasil penelitian yang diuraikan pada tablel 1 menunjukkan bahwa tingkat pengetahuan perawat IGD tentang initial assessment pada penanganan korban KLL termasuk dalam kategori perpengetahuan baik (80\%). Salah satu faktor yang mempengaruhi tingkat pengetahuan perawat di IGD dr. R. Soedjono Selong adalah jenis kelamin. Pada penelitian ini dapat diketahui bahwa jenis kelamin responden paling banyak adalah laki-laki. Hasil ini sejalan dengan penelitianpenelitian sebelumnya yang menjelaskan bahwa Perawat IGD dengan jenis kelamin laki-laki sangat dibutuhkan dan sangat krusial fungsinya karena perawat laki-laki lebih cekatan dan sigap dalam tindakan, cepat dalam pengambilan keputusan, dan lebih tinggi dalam harapan karirnya sehingga kinerja laki-laki lebih baik di bandingkan dengan perempuan [11-14]. Selain karena hal tersebut, tindakantindakan keperawatan yang dilakukan oleh perawat di IGD juga membutuhkan banyak tenaga seperti resusitasi jantung paru (RJP), mobilitas penuh siaga, dimana tindakantindakan tersebut membutuhkan tenaga ekstra yang dimiliki oleh perawat laki-laki [15].

Selain itu, hasil penelitan ini juga menunjukan bahwa jumlah usia perawat IGD terbanyak yaitu pada rentang usia 2530 (80\%). Usia merupakan salah satu faktor lain yang berpengaruh dalam pengetahuan, keaktifan dan produktifitas seseorang $[16,17]$. Hal ini sejalan dengan teori Mubarok (2011) [18] yang menyatakan bahwa usia dapat mempengaruhi produktifitas dalam bekerja dimana kinerja pada usia produktif (25-30 tahun) menunjukkan kinerja yang lebih baik dan semakin meningkatnya usia seseorang maka akan meningkat juga daya berpikir seseorang dalam menangkap berbagai macam informasi.

Faktor lain juga yang berpengaruh terhadap tingkat pengetahuan adalah pendidikan $[19,20]$ dimana mayoritas perawat IGD dalam penelitian ini merupakan lulusan profesi NERS yang termasuk pada kategori pendidikan tinggi keperawatan di Indonesia. Hasil penelitian ini sejalan dengan teori dari notoatmodjo (2012) [21] bahwa pendidikan berarti pemberian informasi dari seseorang kepada orang lain untuk memahami sesuatu hal. Semakin tinggi pendidikan seorang perawat, maka semakin meningkat pula pengetahun, keahlian dan kemampuan perawat dalam memberikan pelayanan kepada pasien yang datang ke IGD [22].

\section{Respon Time Perawat Tentang Penanganan Kasus Kecelakaan Lalu Lintas}

Berdasarkan hasil penelian pada Tabel 1 dapat diketahui bahwa respon time perawat IGD pada pelayanan kasus kecelakaan lalu lintas termasuk dalam kategori krespon time yang cepat yaitu dalam rentang waktu kurang dari 5 menit. Wilde (2009) [2] telah menunjukkan bahwa respon time perawat sangat penting dalam penyelamatan hidup pasien. Respon time perawat adalah kecepatan atau waktu tanggap pelayanan terhitung sejak pasien datang sampai dengan di lakukannya penanganan. Keberhasilan waktu tanggap atau respon time bergantung kepada kecepatan pemberian pertolongan dan kualitas pertolongan dalam upaya penyelamatan jiwa atau pencegahan terjadinya kecacatan akibat kecelakaan yang dialami oleh pasien [23]. Selain dapat menentukan keluasan kerusakan organ-organ dalam, mekanisme response time dapat juga mengurangi beban biaya pasien dan keluarga [24]. Ketersedian perawat yang kompeten dapat mendukung tercapainya respon time yang baik [17]. Penempatan perawat yang kompeten di IGD akan mempercepat proses kepulangan 
pasien untuk pasien yang cidera ringan dan membantu memulai penanganan bagi pasien yang mengalami cidera berat [23].

Dilihat dari kunjungan pasien di IGD RSUD Dr. R. Soedjono Selong saat ini adalah 1.353 pasien pasien/bulan dengan jumlah perawat sebanyak 25 orang, apabila dihitung berdasarkan rumus ketenagaan, maka kebutuhan tenaga perawat sudah cukup. Hal ini di dukung adanya penempatan perawat yang ditempatkan di IGD RSUD Dr. R. Soedjono Selong sudah terlatih untuk melakukan pertolongan pertama.

\section{Hubungan Tingkat Pengetahuan Perawat Tentang Initial Assesment Terhadap Respon Time Perawat Pada Pelayanan Kasus Kecelakaan Lalu Lintas}

Penelitian ini juga mendeksripsikan temuan bahwa terdapat hubungan yang signifikan antara tingkat pengetahuan perawat IGD tentang initial assessment terhadap respon time perawat IGD pada pelayanan kasus kecelakaan lalu lintas di IGD RSUD Dr. R. Soedjono Selong. Tingkat pengetahuan yang baik dalam respon time cepat dapat membantu pasien kecelakaan lalu lintas dalam keadaan gawat darurat untuk menyelamatkan nyawa atau mencegah cacat sejak pertolongan di rumah sakit [20]. Tingkat pengetahuan dipengaruhi oleh faktor pendidikan, dengan pendidikan yang tinggi dapat menghasilkan lulusan yang memiliki sikap dan pengetahuan yang tinggi dan keterampilan profesional maka pendidikan sangat mempengaruhi pengetahuan [23]. Hal ini sesuai dengan pernyatan notoatmodjo (2010) [25] bahwa seseorang yang memiliki pendidikan tinggi maka semakin banyak pengetahuannya dalam menangani pasien gawat darurat. setiap tindakan pada kondisi gawat darurat harus efektif dan efisien karena pasien dapat kehilangan nyawa dengan cepat atau mengalami kecacatan. Nafas yang terhenti selama 2-3 menit pada manusia dapat mengakibatkan kematian yang fatal [26]

\section{SIMPULAN}

Berdasarkan hasil penelitian dan pembahasan diatas dapat disimpulkan bahwa ada hunungan yang signifikan antara tingkat pengetahuan perawat tentang initial assessment terhadap respon time perawat pada pelayanan kasus kecelakan lalu lintas. Sebagian besar tingkat pengetahuan perawat tentang initial assessment di IGD RSUD Dr. R. Soedjono Selong tergolong dalam kategori baik, dengan Respon time perawat tentang penanganan kasus kecelakan lalu lintas yang tergolong cepat.

\section{UCAPAN TERIMAKASIH}

Ucapan terimakasih peneliti diberikan kepada seluruh resonden dan RSUD Dr. R. Soedjono Selong, serta seluruh pihak yang telah membantu dan mendukung seluruh proses penelitian ini.

\section{REFERENSI}

[1] Rosyidi K. Muskuloskeletal. Jakarta: Trans Info Media; 2013.

[2] Wilde, E T. Do Emergency Medical System Response Times Matter For Health Outcome. Columbia University, 2009.

[3] Jayasekera P, Dassanayake G, Bandara K, Jayawardhena L, Malkanthi KMS. A Study of the Pattern of Admissions to the Accident and Emergency (A\&E) Department of a Tertiary Care Hospital in Sri Lanka. Emerg Med Int 2020;2020:1-12.

https://doi.org/10.1155/2020/6327293.

[4] Chang F-R, Huang H-L, Schwebel DC, Chan AHS, $\mathrm{Hu}$ G-Q. Global road traffic injury statistics: Challenges, mechanisms and solutions. Chinese J Traumatol 2020;23:216-8. https://doi.org/https://doi.org/10.1016/j.cjte e.2020.06.001.

[5] Qoriyah, N M. Perbedaan Kelelahan Mata yang Terpapar Silau dalam Mengemudi Angkot pada Siang Hari dan Malam Hari Trayek Johar Banyumanik. J Kesehat Masy 2012.

[6] Dishub N. Kurangi Angka Kecelakaan Lalu Lintas, Kepala Dinas Perhubungan NTB ajak generasi muda membangun budaya tertib lalu lintas! 2020.

[7] KBRN. Kasus Laka Lantas di Lombok Timur Turun 40 Persen 2019. 
[8] Oman, Kathleen S. Panduan Belajar Keperawatan Emergensi. Jakarta: EGC; 2008.

[9] Suryono. Buku Proses Pengkajian Pasien Gawat Darurat. Jakarta: Trans Info Media; 2010.

[10] Iswanto. Hubungan Tingkat Pengetahuan Perawat Tentang BLS (basiclife support) di IGD RSUD Dr. Moewardi Surakarta. Universitas Sahid Surakarta, 2010.

[11] Muzaputri. Standar Tenaga keperwatan Di IGD RSUD Dr. Moewardi Surakarta. Universitas Sahid Surakarta, 2008.

[12] Mao A, Wang J, Zhang Y, Cheong PL, Van IK, Tam HL. Male nurses' dealing with tensions and conflicts with patients and physicians: A theoretically framed analysis. J Multidiscip Healthc 2020;13:1035-45. https://doi.org/10.2147/JMDH.S270113.

[13] Rubio-Navarro A, García-Capilla DJ, TorralbaMadrid MJ, Rutty J. Decision-making in an emergency department: A nursing accountability model. Nurs Ethics 2020;27:567-86. https://doi.org/10.1177/0969733019851542.

[14] Johnston A, Abraham L, Greenslade J, Thom 0, Carlstrom E, Wallis M, et al. Review article: Staff perception of the emergency department working environment: Integrative review of the literature. EMA - Emerg Med Australas 2016;28:7-26. https://doi.org/10.1111/17426723.12522 .

[15] Walgito B. Asuhan Keperawatan Gawat Darurat. Jakarta: Trans Info Media; 2009.

[16] Abraham LJ, Thom O, Greenslade JH, Wallis M, Johnston ANB, Carlström E, et al. Morale, stress and coping strategies of staff working in the emergency department: A comparison of two different-sized departments. EMA - Emerg Med Australas 2018;30:375-81. https://doi.org/10.1111/1742-6723.12895.

[17] Suleiman K, Hijazi Z, Al Kalaldeh M, Abu Sharour L. Quality of nursing work life and related factors among emergency nurses in Jordan. J Occup Health 2019;61:398-406. https://doi.org/10.1002/1348-9585.12068.

[18] Mubarok. Buku Ajar Fisiologi Kedokteran. Edisi 11. Jakarta: Buku Kedokteran EGC; 2011.

[19] Al-Metyazidy H, Elsayed A, Diab S. Relationship between Nurses' Knowledge, Practice and Accuracy of the Patients' Triage Acuity Level in the Emergency Department. Nov Res Healthc Nurs 2019;6:1383-98.

[20] Abebe AM, Kassaw MW, Shewangashaw NE. Assessment of knowledge and practice of nurses on initial management of acute poisoning in Dessie referral hospital Amhara region, Ethiopia, 2018. BMC Nurs 2019;18:1-8. https://doi.org/10.1186/s12912-019-0387-2.

[21] Notoadmodjo. Pendidikan dan Perilaku Kesehatan. Jakarta: Rineka Cipta; 2012.

[22] Aloyce R, Leshabari S, Brysiewicz P. Assessment of knowledge and skills of triage amongst nurses working in the emergency centres in Dar es Salaam, Tanzania. African J Emerg Med 2014;4:14-8. https://doi.org/10.1016/j.afjem.2013.04.009.

[23] Tartila DYR, Wahyudi AS, Qona'ah A. Determinant of Nurses' Response Time in Emergency Department When Taking Care of A Patient. Indones Nurs J Educ Clin 2020;5:125. https://doi.org/10.24990/injec.v5i2.305.

[24] Mutiarasari D, . M, Puspasari I. Response Times and Patient Satisfaction in Emergency Room at Anutapura General Hospital, City of Palu. J Curr Med Res Opin 2019;02:152. https://doi.org/10.15520/jcmro.v2i05.165.

[25] Notoatmodjo S. Metodologi Penelitian Kesehatan. Jakarta: Rineka Cipta; 2010.

[26] Sutawijaya, R B. Gawat Darurat. Yogyakarta: Publishing; 2009. 